\title{
TAKING STRATEGIC DECISIONS IN THE CONTEXT OF ORGANISATIONAL RESTRUCTURING ON THE EXAMPLE OF A MEDIA COMPANY
}

\author{
Mariusz SZUSTER \\ Time S.A., Radio Eska S.A., Grupa ZPR; mariusz.szuster3108@gmail.com
}

\begin{abstract}
Purpose: The aim of the article is to illustrate how important strategic decisions are throughout the process of organisational restructuring and to evaluate the entire process.

Design/methodology/approach: Case study of ZPR Group, a media company that operates in Poland.

Findings: The analysis presented here on the example of the consolidation of the ZPR Group's sales departments may serve as a starting point for further in-depth analyses which will take into account the aspects of organizational restructuring.

Research limitations/implications: The article is based on a case study of the selected organization and in the future this research could be developed in other organizations of this sector or as part of comparative analysis with organizations from other sectors.

Practical implications: The article presents a practical assessment of organizational restructuring in the media sector.

Social implications: The article presents the social dimension of restructuring processes to some extent.

Originality/value: The article presents restructuring and consolidation processes in the media industry.
\end{abstract}

Keywords: restructuring, organisational restructuring, media sector.

Category of the paper: Viewpoint.

\section{Introduction}

This article discusses the process of taking strategic decisions in the context of organisational restructuring. It is important to bear in mind that restructuring is never a single, isolated phenomenon and its implementation does not necessarily mean that a given entity is experiencing a crisis. Such changes are also introduced in well-managed organisations in order to further strengthen their operations. Modifying a company's strategic approach by changing its organisational structure is becoming a popular business practice. This is particularly evident 
in the contemporary market, characterised by extremely fierce competition in virtually every industry.

The reflections presented here are of theoretical and empirical nature. The aim of the article is to illustrate how important strategic decisions are throughout the process of organisational restructuring and to evaluate the entire process based on a case study of ZPR Group, a media company that operates in Poland.

\section{The concept and types of restructuring}

The concept of restructuring has been characterised very precisely by many authors. For example, Borowiecki defines restructuring as a systemic reconstruction, modernisation and adjustment of the structure and operating rules of an enterprise, an organisation or other objects of economic research. According to him, it is a process which seeks to diversify an organisation's activity, modernise its production structure, implement new production technologies, improve quality, drive sales, etc. The aim of restructuring is to ensure a better strategic position of a given company in the market and consequently its better performance (Borowiecki, 2014, pp. 17-18). Based on these suggestions, one may conclude that restructuring is a change implemented by a company in order to enhance its business activity.

Pierścionek reaches similar conclusions when he states that restructuring embodies a specific approach to a company interested in achieving and maintaining its competitive advantage and growth. Its primary focus is to permanently reduce manufacturing costs by lowering the labour costs, eliminating inefficient products and markets, and implementing relatively new technologies and management structures. In this sense, restructuring is based on a company's existing resources and does not seek to create new resources or skills. Restructuring may be related to experimental or imitation methods (benchmarking) (Pierścionek, 2003, p. 64).

Romanowska and Trocki offer another interesting definition when they say that restructuring may be understood as a complex process of significant changes taking place in an organisation with the aim of shaping its attributes, both current and long-term, in the context of the constantly-evolving environment and said company's internal needs. In this approach, client requirements come to the fore. Due to the extremely complex nature of the restructuring process, it would be very difficult to talk of individual clients - or even groups of clients. During the restructuring process, the owner of an organisation (shareholders, stockholders) is considered to be the most important client. Another important and big group of clients are a company's employees and their families. Furthermore, there are other clients that need to be taken into account: users, suppliers, banks and insurance companies. Local governments and the state constitute yet another group (Romanowska, and Trocki, 2004, pp. 43-44). 
For the process of restructuring to be effective, all stakeholders must be carefully analysed this is usually one of the first stages of the restructuring process. It is only after the environment and other related factors have been thoroughly studied that one can move on to implementing the respective restructuring measures (Romanowska, and Trocki, 2004, pp. 43-44).

In other words, company restructuring may be understood as a well-thought-out reorientation of an organisation's goals (mission) that corresponds to past or future changes in its environment, and its adaptation to the above in terms of technology, organisation of work, economics and human resources (Nalepa, 1998, p. 21).

Restructuring on its own is not a uniform term (particularly, the scope of its meaning is not uniform, which is why authors often speak of restructuring types). In this sense one may name a number of different types of said process. Different authors offer different classifications of restructuring based on specific criteria. For example, Borowiecki and Kwieciński distinguish the following types of restructuring (criterion: a situation that triggers restructuring changes and a given company's current life cycle) (Borowiecki, and Kwieciński, 2001, pp. 25-27):

- Creative restructuring, which is implemented independently, regardless of current or anticipated changes in an organisation's environment. Its aim is to, for example, drive the implementation of appropriate changes in a company's environment.

- Anticipatory restructuring, which is implemented by the top management in anticipation of significant changes that are about to occur in an organisation's environment. With accurate forecasts and appropriate responses to said forecasts, a company may be the first to adapt to external changes and thus gain a competitive advantage in the market.

- Adjustive restructuring (or adaptive restructuring), which involves a set of modifications implemented swiftly and effectively as a reaction to changes in the environment. Taking quick action and responding accurately may prove crucial in preventing a company's position in the market from deteriorating.

- Recovery-focused restructuring, which is a variant of adaptive restructuring under which short-term measures are implemented in order to restore a company's stability and efficiency levels.

Due to the spheres affected by it, restructuring process may also be divided into the following two types (Rojek, 2016; Grynchyshyn, 2015; Borowiecki, and Kwieciński, 2001):

- Operational restructuring, which involves changes in a company's core business activity - mainly the state and the structure of its assets. This type of restructuring focuses primarily on three areas: marketing, products and resources. The aim of marketing restructuring is first and foremost to boost sales and thus increase revenues as well as to strengthen a company's market position by, for example, introducing a flexible pricing policy. Product restructuring includes changes to the existing product range and manufacturing processes which result in reduced production costs. Restructuring of a company's resources, on the other hand, involves increasing the efficiency of said 
organisation's broadly understood assets and human resources so as to ensure its compliance with the market standards. Restructuring of a company's resources may also refer to changes in technology or employment.

- Financial restructuring, which covers activities implemented with respect to tangible assets as well as planning and managing an organisation's finances. Its task is to ensure a company's liquidity, appropriate capital structure and to increase its financial capacity and performance. This type of restructuring should lead to internal changes in a company, contributing to its better adaptation to external conditions, which in turn should help it achieve its aims and objectives and succeed in the market.

Some authors also indicate that restructuring in practice means modern, radical and profound changes in crucial areas of a company's activity, which are made to enhance its efficiency and effectiveness in terms of its operations, structure and operating principles. Such changes may be implemented and evaluated from the following three perspectives (Rojek, 2016; Grynchyshyn, 2015; Borowiecki, and Kwieciński, 2001):

- Macroeconomic restructuring (the so-called macro-restructuring), which refers to when changes are implemented with respect to the structure of the state economy and actions that are taken in order to accelerate its general development.

- Mesoeconomic restructuring (the so-called meso-restructuring), which refers to when changes are implemented with respect to the structure and management system in specific economic regions or sectors in order to achieve particular economic goals.

- Microeconomic restructuring (the so-called micro-restructuring), which refers to when changes are implemented only with respect to individual companies in order to adapt them to the evolving market and also its requirements in terms of the macroeconomic situation.

Such types of restructuring may be found across business processes currently observed in the economy. The table below presents other possible classifications.

Table 1.

Selected classifications of company restructuring

\begin{tabular}{|c|c|c|}
\hline Author & Criterion & Type \\
\hline B. Pełka & $\begin{array}{l}\text { Area of a company's operation in } \\
\text { which changes are implemented }\end{array}$ & Objective, subjective \\
\hline J. Gościński & $\begin{array}{c}\text { Area in which changes are } \\
\text { implemented }\end{array}$ & Tangible, organisational, capital \\
\hline $\begin{array}{c}\text { D. Kowalczuk-Jakubowska, } \\
\text { A. Malewicz }\end{array}$ & $\begin{array}{l}\text { Types of actions undertaken in a } \\
\text { company }\end{array}$ & Recovery-focused, developmental \\
\hline Industrial Development Agency & $\begin{array}{c}\text { Area in which changes are } \\
\text { implemented }\end{array}$ & Commercial, financial \\
\hline H. Jagoda, J. Lichtarski & Situation which causes changes & $\begin{array}{c}\text { Creative, anticipatory, adjustive, } \\
\text { recovery-focused }\end{array}$ \\
\hline
\end{tabular}

Source: Gulski, B. (1998-1999). Rodzaje restrukturyzacji przedsiębiorstw, Annales Universitatis Mariae Curie-Skłodowska. Section H, Oeconomia, No. 32-33, p. 116. 
In his publication, Gościński distinguishes one more type of restructuring: organisational restructuring. It is characterised in greater detail in the following section and then further discussed in the empirical part of this article.

\section{Characteristics of organizational restructuring}

One of the types of restructuring is organizational restructuring. As indicated by the name, it refers to modifying the internal structure of a company by adapting said company's internal organisation and procedures to its general business strategy. In practice, organisational restructuring, understood as a fully independent process, is typically triggered by a decline in a company's performance and limited opportunities for its improvement, which in turn translates into reduced effectiveness. This type of restructuring may also be driven by a fall in a company's share in the market, an increase in competition, higher costs, or outdated technology, the latter of which renders a company incapable of keeping up with the most recent technological trends. Suszyński describes organisational restructuring as a process of shaping a company's subjectivity, which goes beyond any changes in its organisational structure. This means that the very necessity of implementing changes in the structure of an organisation does not automatically provide grounds for applying organisational restructuring in practice (Suszyński, 2003, p. 193).

As far as organisational restructuring is concerned, one can point to a number of activities and areas where it may be applied, as briefly presented in Figure 1.

An extremely complicated problem arises in connection with organisational restructuring. It is typically perceived as an autonomous type of operational restructuring because it concerns the operating activity (core business) of a company while being directly related to the structure of a company's finances and its actual operations. Therefore, the role of organisational restructuring is unique as it must cover changes in terms of a company's operations as well as those occurring across its financial structure. Its primary goal is to introduce a company to a new, higher level of functioning and to create a more efficient and effective organisation, which is of great importance, particularly in terms of a company's future operations. While developing a restructuring plan, one may consider the following key areas in organisational restructuring distinguished by Nalepka based on the nature of projects and measures which are to be implemented (Nalepka, 1999, p. 42):

- Rationalisation of the organisational form:

- Establishing of cost centres;

- Establishing of strategic business units;

- Division of companies and founding of independent business entities;

- Selection of appropriate organisational solutions. 
- Improvement of the organisational structure:

- Complete diagnosis of the organisational structure;

- Designing an improved organisational structure;

- Implementation of changes in terms of structural solutions.

- Improvement of rules and methods of operation:

- Lean management, reengineering or kaizen;

- A comprehensive quality management process;

- Targeted costs.

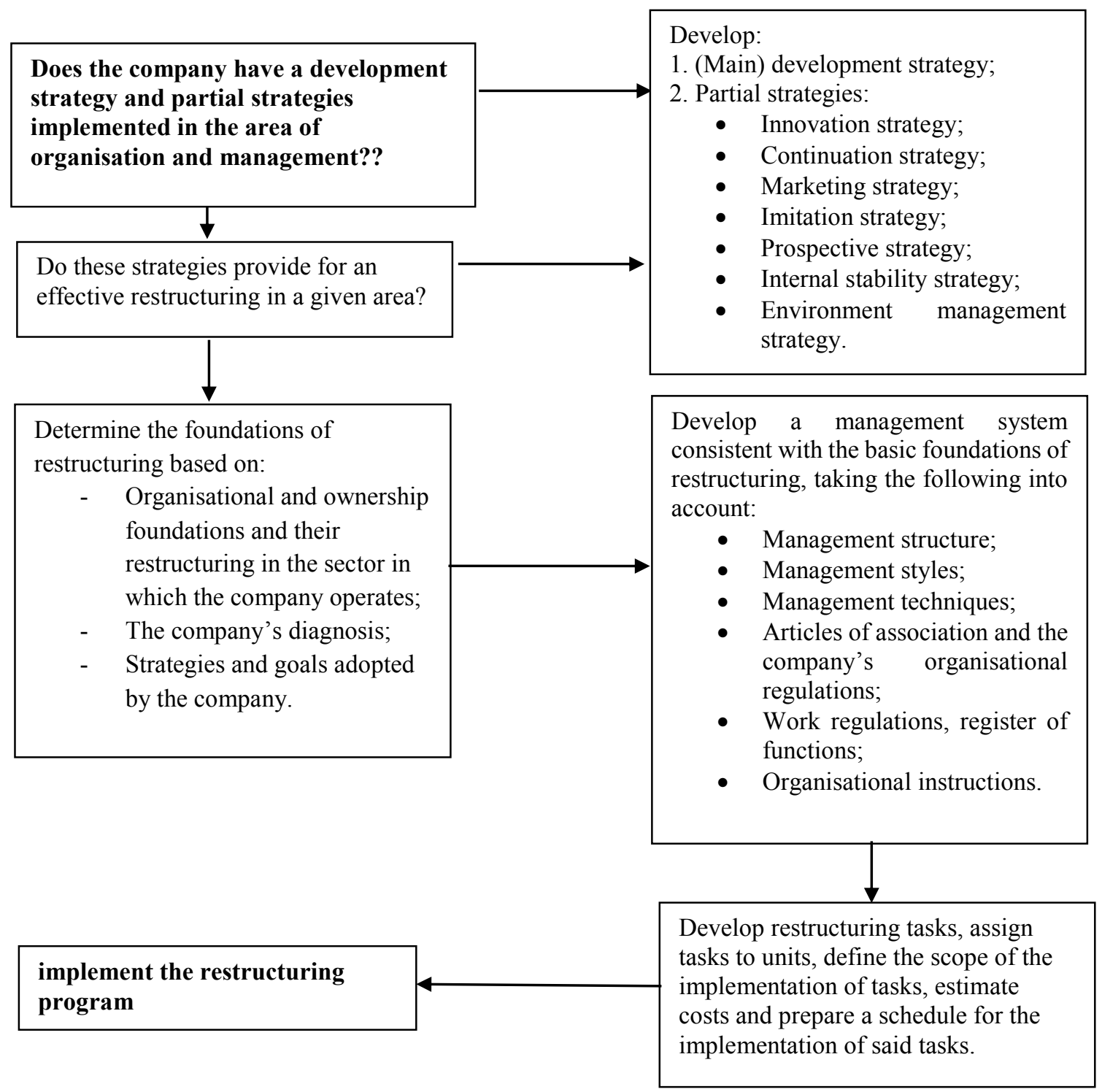

Figure 1. Organisational restructuring and its management approached as a process. Source: Mozalewski, M. (2010). Rodzaje i metody restrukturyzacji przedsiębiorstw, RPEiS, No 2, p. 224. 
This description illustrates the complexity of organisational restructuring in companies. Being aware of its hierarchy and classification, entrepreneurs may plan and gradually implement a restructuring process for their company and then coordinate the process of organisational restructuring against changes that may occur in other areas of their company's activity (Lachiewicz, and Zakrzewska-Bielawska, 2005, p. 38).

This type of restructuring is carried out with the use of different tools. The figure below presents their general typology.

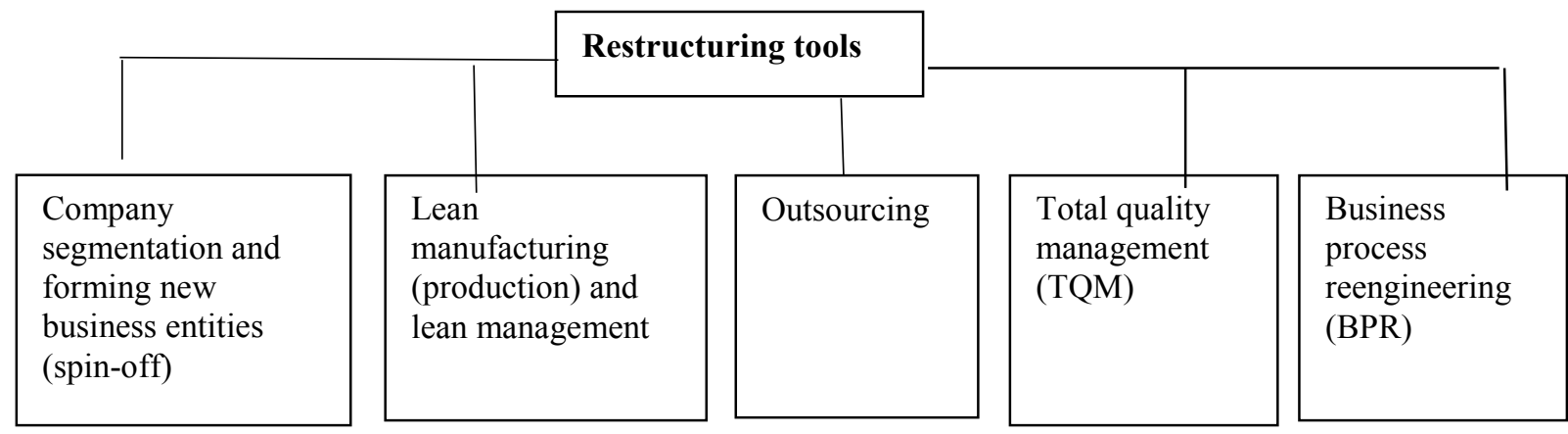

Figure 2. Main tools applied in organisational restructuring. Source: Mozalewski, M. (2010). Rodzaje i metody restrukturyzacji przedsiębiorstw, RPEiS, No 2, p. 225.

\section{Methodology of the empirical research (case study)}

\subsection{Methodological foundations of the author's own study}

The aim of the empirical part of this research is to indicate the most effective way in which organisational restructuring can be carried out - on the example of a media company.

In the context of this solution, particular attention will be paid to changes in:

- Management structure;

- Organisational structure in the company's head office and its regional branches;

- Employment structure.

The analysis is carried out with respect to the ZPR Group - a company operating in the media sector. Case study was chosen as a research method. As shown by source literature, it is a research method that enables a broad description of a specific phenomenon while aiming to rigorously analyse and evaluate said phenomenon. It is a qualitative study that may refer to many scientific disciplines. Using various data collection and analysis techniques, it makes it possible to solve scientific and practical problems (Głowacka, 1986). 


\subsection{Description of the studied organisation}

The ZPR Group is a multimedia holding that includes radio, television, magazine, press and Internet companies. The organisation's business activity and significance in the market is illustrated by the statistics presented below. Firstly, it was necessary to define the groups of users of the media channels offered by the company. Figure 3 presents the detailed data in this respect.

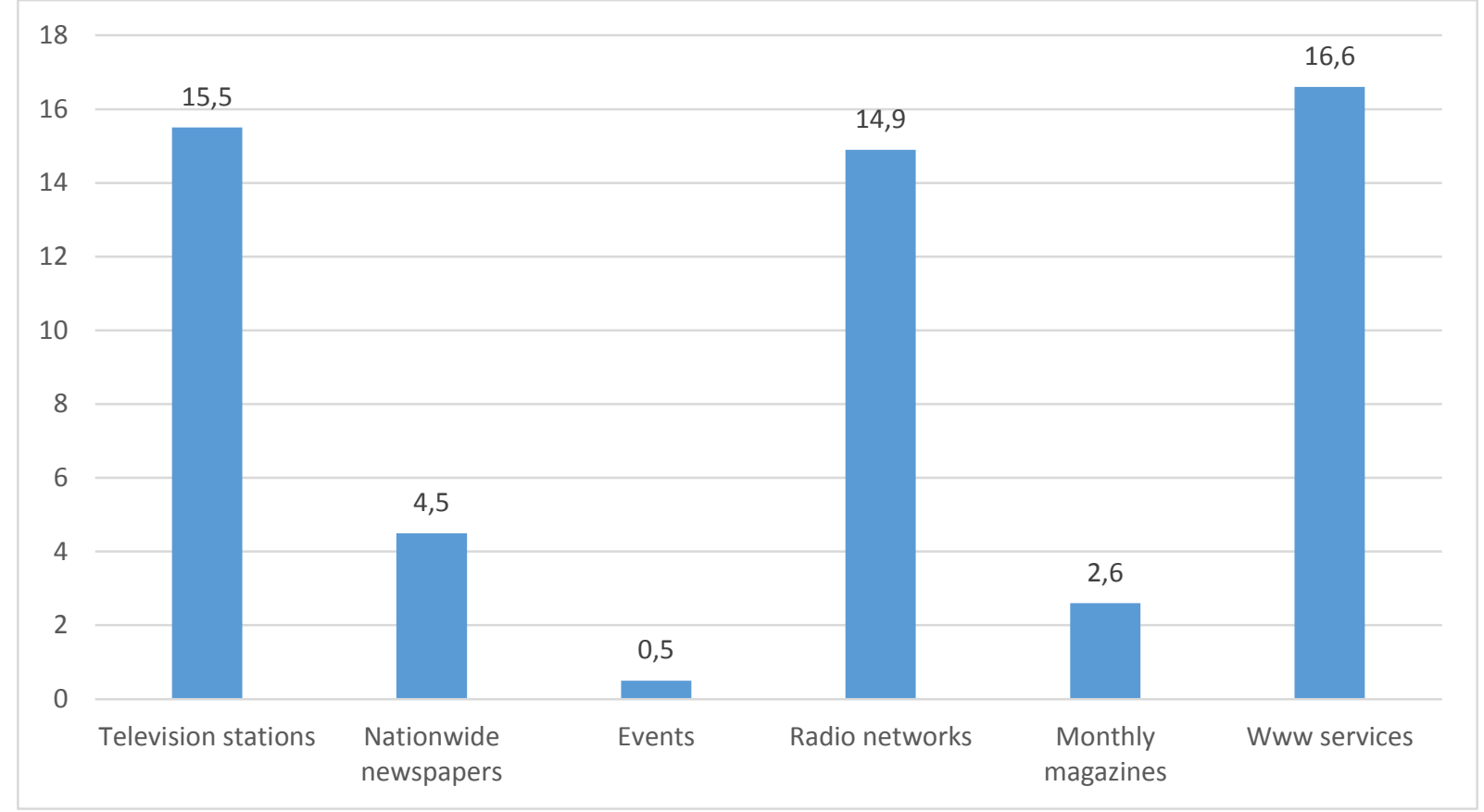

Figure 3. Users of the ZPR Group's media channels (in million per month). Source: Own study based on the data provided by the ZPR Group.

Based on the data presented in Figure 1, one may notice that the ZPR Group has a significant group of users. It reaches them both with traditional media channels (e.g. press, radio) and electronic, innovative media (the Internet). Diversity is the company's particular strength; however, its activity is most developed in the field of online media. According to the data provided by the studied company, the ZPR Group administers:

- 35 own websites;

- 125 partner websites.

One of the areas of the ZPR Group's activity online is social media. In total, it operates as many as 70 social media profiles. It is worth pointing out that it administers the biggest Facebook media fan page in Poland, Radio ESKA, which has as many as two million likes.

Moreover, the ZPR Group runs five radio stations. It ranks second in Poland in terms of the number of radio listeners and is surpassed only by the RMF Group. The ZPR Group also manages one national weekly and eight monthlies. 


\subsection{Analysis of decision-making processes in the course of organisational restructuring on the example of the ZPR Group}

In 2017, the company's owners and management board decided to consolidate the following entities: the magazine Murator and the radio network Time SA. The former publishes eight monthlies - specialist magazines covering the following areas: construction, interior design, health and parenting, hobbies and customs, as well as websites directly related to its press titles. The latter is a company that manages five radio networks: the well-known and highly-popular Radio Eska, followed by Vox, Wawa, Plus and a rock station in Warsaw - Eska Rock.

All of the companies had their own separate management boards, managerial staff, offices, IT facilities and numerous sales departments in Warsaw and across Poland. Both companies had a partial matrix organisational structure depending on specific tasks which required specifically dedicated project teams. They were composed of employees already divided into organisational units, including promotion, editorial and sales staff. Administratively, employees in regions reported to regional directors, while in terms of the content they were supervised by the heads of the respective divisions in the head office.

The consolidation of the companies was initiated primarily for cost optimisation purposes. It turned out that the entire structure could be managed much more effectively by reducing multiple fixed costs resulting from the double structure of the merged entities. With joint accounting, HR, IT and administration, the Group was able to achieve considerable savings on fixed costs. A more ergonomic use of the radio company's office space allowed the employees from the head offices of both companies to be located in one place.

Furthermore, all IT systems, programmes for recording and invoicing sales and customer databases are now shared by employees of the merged companies. At this point it is worth mentioning the market position of the radio company which for many years generated constant revenue growth of several percent year on year, providing financial surplus for investing in work streamlining and automation systems. On the other hand, due to a general market slump in the printed press, the company's press activity was in decline for several years. Despite its efforts to diversify the product offered and 'save itself' with intensified online activity, negative dynamics of revenues were observed in many segments. Considering the company's financial situation, further investments were rendered impossible. Therefore, the levels of prosperity and development of both companies were not even.

The consolidation process itself did bring the expected cost savings, while the knowledge, tools and experience of the employees became a joint asset of the merged companies. The consolidation process concerned many aspects; however, this article focuses on the consolidation of the sales departments. Shortly after the merger a decision had to be taken regarding these units. One possibility was to merge them - similarly to other departments of both companies. However, a question arose regarding whether maybe, in this case, it would be better to preserve the current configuration. At a later stage of the restructuring process 
an analysis of both options revealed yet another idea: a compromise between the two previous concepts.

The press company had a few sales departments: the main department with the largest staff in the company's head office in Warsaw, and several two- or three-person teams in Poland's major cities: Wrocław, Poznań, Łódź, Kraków, Katowice, Tricity, Szczecin, Lublin, Białystok and Rzeszów. Each city had a manager responsible for sales in the given branch who reported to the director of the given segment in Warsaw. Just before the consolidation, several regional sales positions in the press company were reduced. This was naturally related to noncompliance with the sales plans and the falling sales in the respective branches.

The situation in the radio company was similar, but its scale was larger. There were 39 branches, with each employing between 1 and 10 people, depending on the revenue potential generated by the given city. Next to Radio Eska, the leading radio station in the Polish radio market, some cities also have other stations in their offer, such as Wawa, Vox or Plus, as well as Eska Rock in Warsaw. In the 14 biggest cities, the radio company also has, within its sales offer, Eskainfo - a local online information and entertainment portal which complements the radio offer.

The sales teams were grouped into 40 regional branches. Each of the nine regions had its regional director who reported to the deputy commercial director for direct sales in the head office.

In light of the above, the following options were possible:

- To preserve separate sales departments as before the consolidation

This solution had a definite disadvantage: the falling sales of press products. Reduced sales in the area of magazines reflected general market trends in the printed press segment. In addition to this, a more detailed analysis of the sales structure of press advertisements showed that the share of sales generated by the clients of the respective branches had been falling for several years compared to the sales observed in Warsaw (the head office). Among other things, this was a reason for job-cutting (directly before the merger of the companies) in the sales departments of the branches. Further analysis revealed the direct cause of the decline.

Printed magazines have a nationwide circulation and therefore the most reasonable approach is to look for clients with a similar area of coverage. Most companies operating on a larger scale locate their head offices in Warsaw. Readership rates and circulation volumes of printed titles used to be record-breaking, which translated into high sales and profits. At that time, the press company started founding branches outside of Warsaw which developed their own local products. In addition to advertising in the main (nationwide) versions of the magazines, addressed also to clients with a wider area of operation, local versions ('mutations') began to appear with special inserts offering information about local producers and service providers. These products were targeted at local entrepreneurs who conducted their business operations at the regional and supra-regional level. 
Taking into account that nationwide titles at that time were selling in very high circulation volumes, the share of the respective regions in the entire circulation was also a parameter that made it possible to generate high sales for the given branch. Unfortunately, after the press market collapsed and the nationwide periodicals had to cut their circulation volumes drastically, local inserts ceased to be attractive, as their reduced circulation no longer brought comparable business benefits to clients. In 2012-2017, the share of regional insert sales in total revenues from press sales decreased gradually, as shown in Table 2.

Table 2.

Share of inserts (in \%) in total press sales in 2013-2017 in selected regions

\begin{tabular}{|l|c|c|c|c|c|}
\hline Region & Year 2013 & Year 2014 & Year 2015 & Year 2016 & Year 2017 \\
\hline Poznań & 32 & 25 & 24 & 19 & 11 \\
\hline Tricity & 29 & 21 & 23 & 16 & 7 \\
\hline Łódź & 24 & 24 & 15 & 13 & 10 \\
\hline Wrocław & 31 & 32 & 26 & 22 & 13 \\
\hline Katowice & 36 & 25 & 28 & 16 & 8 \\
\hline
\end{tabular}

Source: Own study based on the data provided by the ZPR Group.

The price of the insert modules, which is determined by the number of potential recipients of advertising, would have to fall to the level that does not guarantee the branch reaching the profitability threshold. Preparing inserts generates additional costs (related to the use of especially prepared print matrices, placing inserts in magazines, distribution, acquiring advertisers, etc.) which make sense only provided that a certain minimum level of sales is achieved.

However, the concept of preserving separate sales departments also had a few advantages. First and foremost, the attitude of employees and managerial staff towards this idea was more positive. Merging would naturally entail employment optimisation, which would translate into job reductions. The prospect of the consolidation and subsequent lay-offs in sales departments would result in a falling morale among the employees.

When defending this option, one should also take into account the excellent specialist skills of the employees in selling their products. Many years of experience and knowledge of non-standard solutions is undoubtedly a desirable quality among sales specialists. On top of that, it is also important to remember the main assets of the sales teams: good relationships with the clients.

- Merger of the sales departments

The major advantage of this option was significant cost savings. Similarly to the solution adopted in Warsaw, sales departments in the respective branches could be located in one place. One common office, secretariat, sales support, technical and IT infrastructure could translate into actual savings in branches where next to a radio sales department another one would operate that would be dedicated to press. It also seems obvious to have one sales manager per every merged local sales department, which would constitute another step towards cost optimisation. 
The disadvantage of this solution was substantial disproportions in sales results between the radio and press departments, with the former being on the rise and the latter struggling to deliver on their sales plans. The only exception here was Warsaw, where the sale of magazines was least affected by the aforementioned collapse of the press market. Compared to the years of the press boom, sales in the Warsaw branch fell by approx. 30\%, while in regional branches they fell by approx. $70-80 \%$.

Another problem after the merger of the companies and then consequently their sales departments would be how to communicate with the clients. Before, press products presented by the sales teams from the other company were in no way identified with the radio or the entire group. Radio agents acted based on their already well-established relationships with the clients, competing with other media. In this option, whenever clients were to receive offers or sign contracts, they would quickly realise that they were being contacted by representatives of the same company. In the era of a chronic lack of time and constantly increasing pace of life, they would not be interested in holding separate meetings devoted only to magazines or radio services. They would expect a comprehensive service which, in the absence of employees with specialist knowledge on all products, would be difficult to provide.

Table 3.

List of advantages and disadvantages of both decisions regarding organisational restructuring in the ZPR Group

\begin{tabular}{|c|c|}
\hline Variant: Preserving separate sales departments & \\
\hline ADVANTAGES & DISADVANTAGES \\
\hline $\begin{array}{c}\text { - No resistance from employees to changes in } \\
\text { the organisational structure } \\
\bullet \quad \text { Short-term savings }\end{array}$ & $\begin{array}{l}\text { - No medium- and long-term savings on } \\
\text { business operations (failure to deliver due to } \\
\text { the need for change) }\end{array}$ \\
\hline \multicolumn{2}{|l|}{ Variant: Merging of the sales departments } \\
\hline $\begin{array}{c}\text { ADVANTAGES } \\
\end{array}$ & DISADVANTAGES \\
\hline $\begin{array}{l}\text { - Cost reduction in accordance with the } \\
\text { financial plan of the restructuring } \\
\text { - } \quad \text { Partial slimming down of the organisational } \\
\text { structure } \\
\text { - Streamlining of the decision-making process } \\
\text { in the company } \\
\text { - Clear division of responsibilities }\end{array}$ & $\begin{array}{c}\text { - } \quad \text { Problems in communication with clients } \\
\text { - Difficulties related to convincing employees } \\
\text { to planned changes }\end{array}$ \\
\hline
\end{tabular}

Source: Own study.

After analysing the potential benefits and risks resulting from the implementation of any of the variants, intermediate solutions were also taken into account. When the two variants discussed above turned out to be impossible, an intermediate option was chosen. The aim was to take a decision that would guarantee the maximum use of the opportunities that came with the merger of the companies with the minimum risk of losses in sales.

- A compromise between the two variants and its final implementation

Firstly, the press market was analysed and the potential of different press products in the individual regions was determined. Secondly, the sales potential of sales specialists in the press teams was studied. In local markets, daily newspapers play the leading role, offering relatively 
low advertising costs that small and medium-sized enterprises can afford. Mapping was carried out with respect to major companies and their commercial potential in the respective regions. Several dozen companies representing industries covered in the ZPR Group's magazines were selected, and said companies operate at the nationwide or supra-regional level. For other entities, the purchasing of advertising in the main versions of magazines with nationwide coverage would be unprofitable, significantly exceeding the cost of promoting one's company through other channels. With the relatively low sales of press products, the sales specialists' remuneration also dropped considerably, which affected their motivation to work. Therefore, the press products were divided into two groups.

The first group comprised online advertising on well-functioning websites related to the printed magazines. Unlike printed press with nationwide coverage, online advertising allows companies to promote their products and activities in their fields of business and within the accordingly smaller area of their actual operation. Geo-targeted advertising on press portals perfectly complements the coverage available under the online radio offer. Moreover, the implementation of this product was not complicated because every person involved in selling radio services was also trained in selling websites. This so-far-underused portion of the market potential was transferred to regional radio directors and their teams for further exploration.

The second group of clients in the regions comprised several dozen large companies with whom cooperation was planned in the area of printed magazines but also on the Internet. It turned out that part of this group included active radio clients with many years of relationships with the employees of the sales departments.

In this situation it was decided that a special team would be created consisting of highly professional and ambitious radio account managers from the regions, and said managers then received several months of training in press products. These people worked with the magazine sales specialists and directors so as to be able to, at some point, move on to selling their press products. The company could not afford to overburden its key sales employees, which is why each member of this group was appointed approximately a dozen clients. When preparing more complex offers, they can still benefit from the support of the Warsaw press team and sales support department. Meetings with key clients are attended by combined delegations of people especially appointed for this purpose.

When the compromise variant was implemented, it was finally possible to define the sales directions for individual products in the regions. The tasks of the press departments were handed over to the radio sales specialists, as a result of which the already significantly reduced teams could be dismissed. Some of the best press account managers were included in the radio departments, where after proper training they carried out radio and online press sales. Consequently, the company was able to resign from unnecessary offices and fixed assets, and make considerable savings on employee salaries. 
In the case of the head office in Warsaw, the most optimal decision was to leave both sales units separate. The press department in Warsaw seems to be doing rather well. In addition, most companies with a nationwide potential have their headquarters in Poland's capital city, which provides their employees with easy access to clients. However, both departments use a common IT system to manage their client contacts. Special procedures for the Warsaw market were prepared to increase the synergy effect of the products sold. Clients of the respective sales departments are gradually starting to be managed jointly. Special offers including products of the merged companies were prepared, developed and implemented. Cross-selling services are offered by well-trained sales specialists in packages that are beneficial to advertisers. Due to the specific nature of the industry that they represent, a significant number of clients will continue to cooperate only with one of the sales departments, as entering another field of communication in their case would only increase the costs without delivering the desired effect. Some enterprises that tend to focus on only one type of the offered media were selected as clients with whom cooperation may potentially be extended as a result of cross-media campaigns.

The process of all the discussed changes may be illustrated on a graph. The new organisational structure of the sales departments is shown in Figure 4.

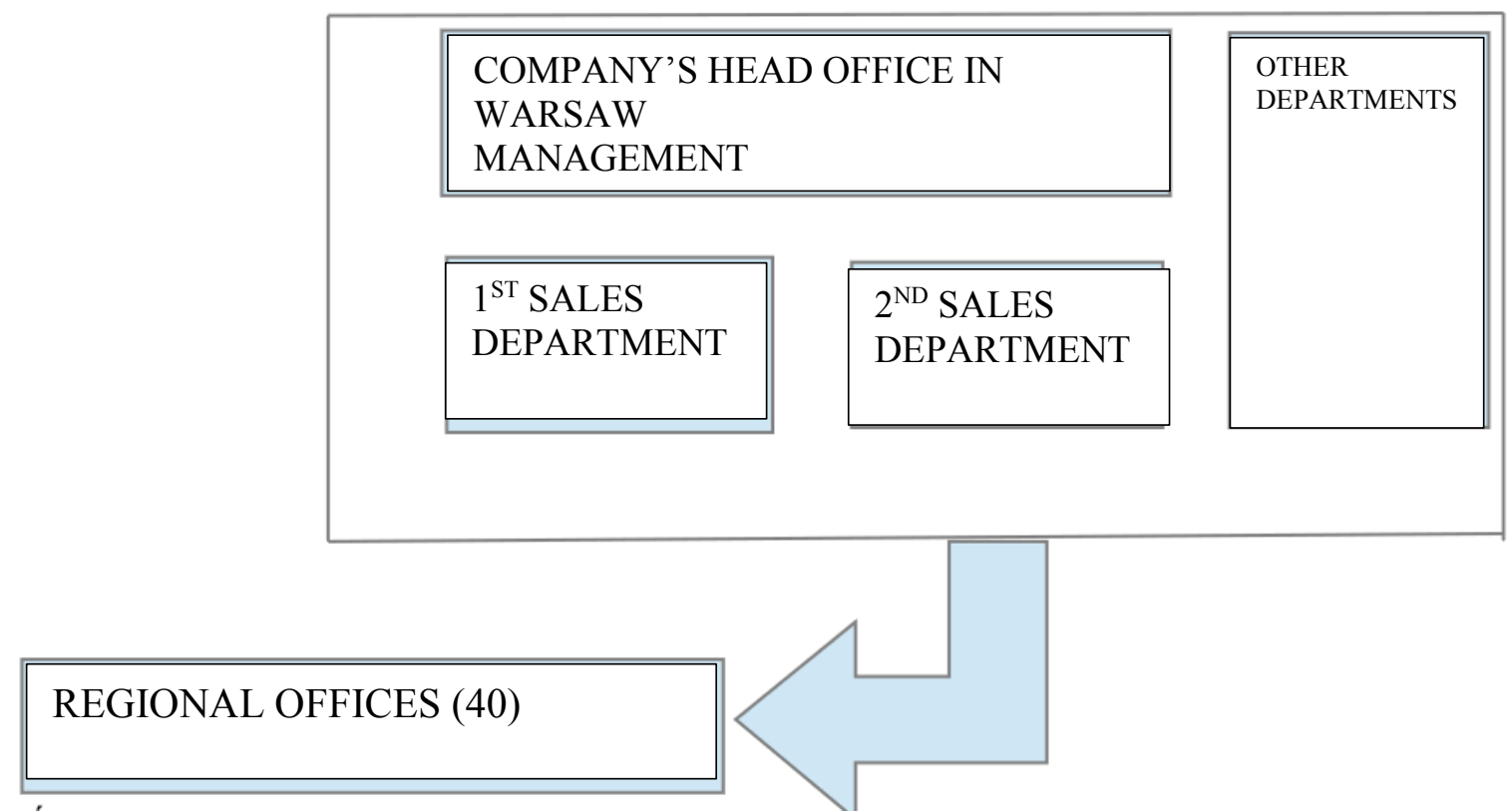

Figure 4. Organisational structure of sales departments - the new version. Source: Own study.

The consolidation process and the decisions enforced by it brought about the expected results. In addition to significant financial savings, the processes of managing the company as a whole and its individual organisational units were simplified considerably. The office space and fixed assets were reduced, thus leading to a better use of the organisational solutions implemented in the merged companies. From the point of view of investment and finance management, it is much easier to process data when it is collected in one place, with one department responsible for accounting, controlling, research and analysis. Before this change, 
the Group was forced to aggregate the figures, while any joint ventures had to be accordingly booked as activities of affiliated entities.

The aims and objectives of the process of change were therefore met only partially. While the company managed to achieve the expected financial targets, the consolidation itself presented a number of significant difficulties, generating additional costs. Undoubtedly, the first stage of the merger process did not take place in the atmosphere of cooperation. Whenever change affects people, their jobs, authority and areas of influence, difficulties arise on the part of employees themselves. In this case, they questioned the adopted strategy, which resulted primarily from their resistance to changes. Unfortunately, the organisational structure of the merged companies was reduced only slightly. Some departments were merged and organisational units whose responsibilities overlapped were liquidated. The number of managers was reduced at all levels of management. Significant reductions also affected regular employees. Nevertheless, it was only during the consolidation of the sales departments that benefits started to be noted (synergy effect and a more open attitude to cooperation), which contributed to decisions which were most optimal in this case.

\section{Conclusions}

Based on this analysis, the following general conclusions regarding organisational restructuring in a company (not only in the ZPR Group but in any other business entity) may be drawn:

- Organisational restructuring of any enterprise is a highly complicated process that requires a well-thought-out plan. Nevertheless, it must be borne in mind that this plan might not always be fully implemented and that not all obstacles and problems might be overcome.

- Organisational restructuring usually leads to reducing a company's organisational structure and costs (typically its main aims).

- In this case, decisions regarding organisational restructuring were taken centrally. However, they were also based on data provided by lower organisational units of the restructured companies.

- One of the key factors in a successful restructuring process is to convince employees to the planned changes.

- In the studied business entity, the original concepts of organisational restructuring could not be implemented in their entire scope. One of the reasons for this was the resistance of employees, which had a significant impact on the company's final decision to opt for the intermediate variant of organisational restructuring. 
- One of the main elements of organisational restructuring in the studied company was the merger of the decision centres, which resulted in a reduction in the number of senior managers.

- The key factor in the successful organisational restructuring in the studied company seems to be the uniform system of management across the entire group.

The analysis presented here on the example of the consolidation of the ZPR Group's sales departments may serve as a starting point for further in-depth analyses which will take into account the aspects of organizational restructuring discussed in the article.

\section{Acknowledgements}

The article is the result of the author's own research conducted as part of his own professional activity.

\section{References}

1. Borowiecki, R. (2014). Zarzadzanie restrukturyzacja przedsiębiorstw i gospodarki. Kraków: Fundacja Uniwersytetu Ekonomicznego.

2. Borowiecki, R., and Kwieciński, M. (2001). Zarzadzanie zasobami informacji w przedsiębiorstwie. Ku przedsiębiorstwu przyszłości. Warsaw: WNT.

3. Głowacka, E. (1986). Metoda case study w badaniach i dydaktyce bibliotekoznawstwa i informacji naukowej, Przeglad Biblioteczny, No. 1.

4. Grynchyshyn, J. (2015). Restrukturyzacja jako narzędzie zarządzania antykryzysowego przedsiębiorstw. Zeszyty Naukowe Uniwersytetu Przyrodniczo-Humanistycznego w Siedlcach, No. 106.

5. Lachiewicz, S., and Zakrzewska-Bielawska, A. (2005). Restrukturyzacja organizacji i zasobów kadrowych przedsiębiorstwa. Kraków: Oficyna Ekonomiczna.

6. Nalepa, A. (1998). Zarys problematyki restrukturyzacji przedsiębiorstw. KrakówKluczbork: Wydawnictwo Antykwa.

7. Nalepka, A. (1999). Restrukturyzacja przedsiębiorstwa. Warsaw: PWN.

8. Pierścionek, Z. (2003). Strategie konkurencji i rozwoju przedsiębiorstwa. Warsaw: PWN.

9. Rojek, T. (2016). Wykorzystanie narzędzi restrukturyzacji w procesie zarządzania efektywnością przedsiębiorstwa. Studia Oeconomica Posnaniensia, 4(2). 
10. Romanowska, M., and Trocki, M. (2004). Podejście procesowe w zarządzaniu. Warsaw: Wydawnictwo SGH [Warsaw School of Economics].

11. Suszyński, C. (2003). Restrukturyzacja, konsolidacja, globalizacja przedsiębiorstw. Warsaw: PWE. 